\title{
Sykehus anno 1917
}

\section{Den første verdenskrig herjet i Europa. Også i Norge vokste sykehusbehovet. I denne artikkelen om Innherred sykehus får vi et innblikk i hvordan et moderne ombygd sykehus i 1917 skulle være (Tidsskr Nor Lægeforen 1917; 37: 187-92).}

\section{Norske sykehuser.}

\section{A. Alm. Sykehuser og epidemisykehuser.}

VI. Ombygningen av Innherred sykehus i Nordre Trondhjems amt.

Ved Olaf Tandberg, sykehusets overlæge, Levanger.

De senere aar har overalt $\mathrm{i}$ landet vist et sterkt stigende behov for sykehusbehandling og dermed øket plads paa sykehusene. (...) Efter forslag av sykehusdirektionen gav amtstinget i 1912 den fornødne bevilgning til planlæggelse av sykehusets ombygning, og samme høst blev 3 arkitekter indbudt til at levere utkast. (...)

Amtstinget vedtok i 1913 enstemmig de fremlagte planer og bevilget den stipulerte sum, kr. 290 500, hvorefter arbeidet paabegyndtes straks. Som byggekomite fungerte sykehusdirektionen, bestaaende av lensmand Bye (formand), ordfører Faanes, standartjunker Okkenhaug og overlæge Tandberg. (...)

Færdigbygget kan Innherred sykehus nu opta 120 patienter, $60 \mathrm{i}$ den nye og $60 \mathrm{i}$ den gamle bygning, foruten epidemiavdelingen paa 16 senger.

Den nye bygning indeholder:
I kj e l d e r e n : Dampkjøkken med 3 dampgryter, poteteskoker, 2 temaskiner og kaffekoker, elektrisk drevet potetesskrællemaskin og kjøtkvern, og almindelig komfyr. Anretningsrum med opvaskmaskin og elektrisk heis til de øvrige etagers anretningsrum. (...)

I $1 \mathrm{ste}$ e tage: 7 sykeværelser med tils. 30 senger, garderobe, anretning, 2 bad, W.C., skyllerom, magasinrum, kontor , laboratorium og spiserum for søstrene.

I $2 \mathrm{den}$ etage; 7 sykeværelser med 30 senger, garderobe, anretning, 1 bad, W.C., skyllerum og operationsavdelingen. Denne bestaar av forværelse, 2 operationsstuer, sterilisationsrum med skapformet sterilisator og destillationsanlæg (begge levert av C. Blunck, Kr.a.), instrumentkoker og elektrisk kokeplate samt bandagerum. (...)

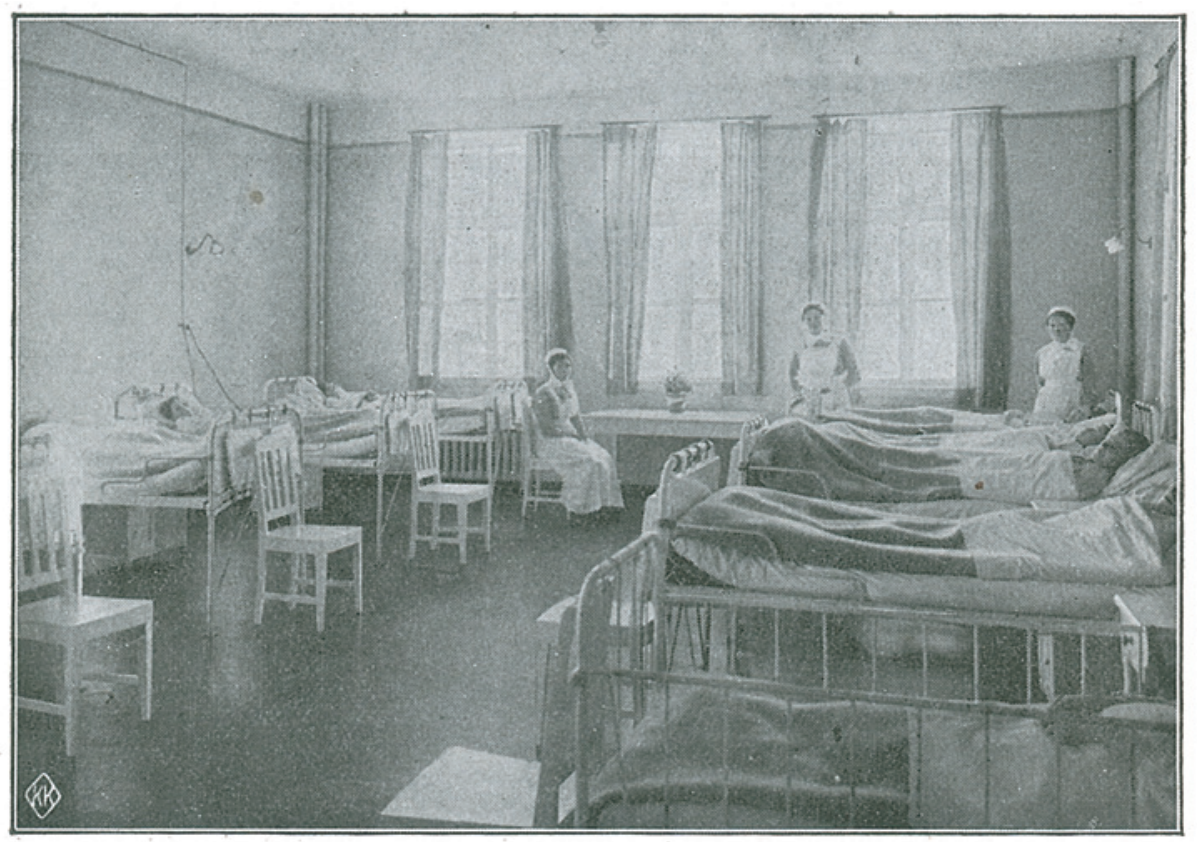

Kvindesalen i 1ste etage. 